https://doi.org/10.18778/7525-969-8.15

\author{
Danuta Gibas-Krzak
}

\title{
Terroryzm islamski na Bałkanach Zachodnich jako konsekwencja rozpadu Jugosławii w świetle badań naukowców bałkańskich oraz zachodnich. Zarys problemu
}

Jedną z najbardziej dramatycznych i złożonych konsekwencji rozpadu federacji jugosłowiańskiej, mająca głęboki wpływ na stan bezpieczeństwa, było powstanie islamistycznej sieci terrorystycznej na terytorium Bałkanów Zachodnich, obejmujacej Bośnię i Hercegowinę (BiH), Macedonię, Kosowo, Sandżak oraz Albanię, która funkcjonuje do dziś, rozwija się, tworząc nowe komórki zagrażające nie tylko stabilności Starego Kontynentu, ale także bezpieczeństwu w skali globalnej. Od rozpadu Jugosławii minęło już przeszło 20 lat, lecz służbom bezpieczeństwa państw postjugosłowiańskich, ani też mocarstw, nie udało się wyeliminować niebezpieczeństwa związanego z islamskim terroryzmem w tym regionie. Istnieją bowiem dowody, że sieć terroryzmu rozrasta się, włączając się do struktur globalnego dżihadu ${ }^{1}$. Główną tezą artykułu jest twierdzenie, że Bałkany stanowią bazę dla islamistów, którzy rekrutują na tym terytorium terrorystów, a także dokonują operacji finansowych niezbędnych dla

${ }^{1}$ Salaficki ruch globalnego dżihadu (ruch globalnego dżihadu, ruch dżihadystów) tworzą organizacje, koncentrujące się wokół założycieli i współpracowników Al-Kaidy: Osamy bin Ladena, Abdullaha Azzama, Ajmana Az-Zawahiriego oraz innych. W szerokim rozumieniu ruch ten obejmuje także niezależne organizacje terrorystyczne, mające podobne cele, ale operujące na własny rachunek. Genezy ruchu należy upatrywać w rewolucji islamskiej w Iranie oraz inwazji radzieckiej na Afganistan. W ten sposób w różnych miejscach globu zaczęło działać ponad 100 radykalnych grup islamistycznych, swoistym centrum ruchu stała się zaś Al-Kaida. O jego globalnym charakterze może świadczyć np. pochodzenie członków Brygady 055, walczącej w latach 1997-2001 w Afganistanie, wśród jej członków, oprócz obywateli Egiptu, Algierii, Maroka, Indonezji zanotowano także Muzułmanów z Bośni i Hercegowiny. S. Wojciechowski, Terroryzm na poczatku XXI wieku. Pojęcie, istota i przyczyny zjawiska, Bydgoszcz-Poznań 2011, s. 203-204. Na temat ruchu globalnego dżihadu więcej zob. A. Wejkszner, Ewolucja terroryzmu motywowanego ideologia religijna na przykładzie salafickiego ruchu globalnego dżihadu, Poznań 2010, s. $215-216$ i n. 
swojej działalności, chociaż wielu badaczy nie dostrzega tego problemu, uważając, iż skala niebezpieczeństw związana z fundamentalizmem muzułmańskim $\mathrm{w}$ tym regionie nie ma istotnego znaczenia ${ }^{2}$. Autorka jednak kwestionuje taki pogląd, uważając, że nie prezentuje on właściwie sytuacji społeczno-politycznej w wielu państwach bałkańskich, ani też nie porusza kwestii zagrożenia terroryzmem islamskim, szczególnie w Bośni i Hercegowinie, jak i na całym Starym Kontynencie. Analizy i ekspertyzy serbskich, bośniackich oraz amerykańskich znawców problematyki bałkańskiej posłużyły do uzasadnienia wniosków zawartych w niniejszym artykule.

\section{Geneza terroryzmu islamskiego w Bośni i Hercegowinie}

Terroryzm islamski na Bałkanach wiąże się ze wzrostem wpływów fundamentalistów muzułmańskich, zwłaszcza w Bośni i Hercegowinie. Trzeba jednak podkreślić, że zasady radykalnego islamu nie miały istotnego znaczenia dla większości społeczeństwa wyznającego tę religię w „drugiej” Jugosławii. Chociaż Muzułmanie zyskali w 1971 r. status odrębnej narodowości, to jednak ich religijność była powierzchowna, mając świecki charakter. Innym zjawiskiem był rozwój instytucjonalny islamu, do którego doszło w latach 70. XX w. Powstawało wówczas m.in. wiele nowych meczetów, szkół, wydawnictw, a co roku około 250 młodych ludzi udawało się na studia, zwłaszcza do Iranu, gdzie zdobywali tytuł hodży. Po powrocie do ojczyzny prowadzili oni indoktrynację religijną w społeczeństwie bośniackim ${ }^{3}$. Ponadto wielu imigrantów z Albanii i Bliskiego Wschodu

${ }^{2}$ Często jako główny argument podaje się fakt, że doszło do deportacji mudżahedinów z terytorium Bośni i Hercegowiny - zob. G. Kepel, Święta wojna. Ekspansja i upadek fundamentalizmu muzutmańskiego, Warszawa 2003, s. 256. Zgodnie z postanowieniami traktatu z Dayton, kraj mieli opuścić wszyscy „wojownicy Allaha”. Tak się jednak nie stało, po zakończeniu wojny na terytorium państwa bośniackiego pozostało bowiem około 1,5-2 tys. mudżahedinów. Dopiero w 2007 r. rząd zdecydował się pozbawić obywatelstwa bośniackiego prawie 400 „wojowników Boga”. Zgodnie z danymi amerykańskiej Roboczej Grupy ds. terroryzmu i niekonwencjonalnego prowadzenia wojny, w kwietniu 1996 r. na terenie Bośni działało 4-6 tys. islamskich wojowników dżihadu, którzy byli zakonspirowani w organizacjach humanitarnych oraz zatrudnieni w armii i policji - zob. D. Džamić, Psi rata na Balkanu. Strani plaćenici u ratnim sukobima na prostorima bivše Jugoslavije, Beograd 2001, s. 247; D. Gibas-Krzak, Terroryzm i radykalny islam - zagrożeniem dla wieloetnicznej Bośni i Hercegowiny (mps artykułu), s. 14.

${ }^{3}$ Hodża - turecki termin oznaczający duchownego, który uzyskał wykształcenie w medresie; nauczyciel religii. Wykształceni na Bliskim Wschodzie młodzi Bośniacy, począwszy od lat 80. XX w., rozpowszechniali w swojej ojczyźnie idee najbardziej radykalnego odłamu islamu - wahhabizmu, stanowiącego oficjalny kierunek religijny w Arabii 
przybywało do Bośni, wywierając wpływ na radykalizację miejscowego środowiska muzułmańskiego $0^{4}$.

Terroryzm fundamentalistyczny sensu largo pojawił się natomiast na Bałkanach jako dziedzictwo wojny domowej w Bośni i Hercegowinie, chociaż już w latach 80. XX w. na terytorium Jugosławii istniały bazy palestyńskich i libańskich terrorystów, w których m.in. Hezbollah rekrutował Bośniaków do grup terrorystycznych ${ }^{5}$. Wielu spośród miejscowych muzułmanów odbywało szkolenia w Libanie i Iranie, następnie, po powrocie do kraju, prowadzona przez nich fundamentalistyczna indoktrynacja sprawiała, że radykalne nurty islamu zyskiwały coraz więcej zwolenników. Jednocześnie władze federacyjnej Jugosławii uważały, że ruch ten nie był na tyle groźny dla stabilizacji państwa, aby trzeba go było spacyfikować. Bezpośrednim bodźcem do aktywizowania islamistów w Bośni stało się zwycięstwo rewolucji Chomeiniego, kiedy to politycy irańscy otwarcie zarzucili władzom Jugosławii prześladowanie religii muzułmańskiej ${ }^{6}$. W ocenie badaczy serbskich, Alija Izetbegović ${ }^{7}$ odnowił wówczas wezwanie do stosowania jego Islamskiej Deklaracji, dając początek zorganizowanemu politycznemu ruchowi islamistycznemu w Bośni. Należy więc podkreślić, iż poczattki terroryzmu fundamentalistycznego na tym terytorium wiążą się z radykalnymi odmianami islamu, które udało się zaszczepić jeszcze w okresie „drugiej” Jugosławii, pod rządami Josipa Broz-Tity, chociaż z pewnością mógł się on rozwinąć na szeroką skalę

Saudyjskiej, który uznaje wyższość islamu nad wszystkimi religiami oraz potrzebę dominowania nad nimi. Często bywa też utożsamiany z salafizmem, który stanowi jednak bardziej ogólny ruch religijny i polityczny, majaccy na celu odrodzenie islamu poprzez powrót do pierwotnych źródeł tej religii. Fundamentalizm muzułmański polega na powrocie do Koranu jako jedynego, prawdziwego źródła wiary, orientuje się na wczesny islam, kiedy istniała jedność ummy, czyli muzułmańskiej wspólnoty, ma na celu stworzenie gminy muzułmańskiej, w której szaria (prawo muzułmańskie) reguluje wszystkie dziedziny życia zob. M. i U. Tworuschka, Islam. Mały słownik, Warszawa 2005, s. 50-51. O twórcy wahhabizmu, Muhammadzie Ibn Abd al-Wahhabie więcej zob.: A. Wejkszner, dz. cyt., s. 140-141.

${ }^{4}$ Dla Teheranu Bośnia szybko stała się miejscem eksportu rewolucji. Celem Chomeiniego było bowiem przekonanie wspólnoty muzułmańskiej do udzielenia poparcia bośniackim Muzułmanom. Badacze serbscy podkreślili, że Alija Izetbegović znalazł się w centrum systemu islamistycznego w Europie jako członek organizacji muzułmańskiej „Fidajena”, której celem od końca lat 60 . XX w. stało się propagowanie walki o rozpowszechnienie islamskiego sposobu życia i uczynienie z Bośni republiki islamskiej - zob. M. Drecun, Alahovi ratnici, Beograd 2008, s. 78-80.

5 Tamíe.

${ }^{6}$ N. Beloff, Tito's flawed legacy. Yugoslavia and the West: 1939-84, London 1985, s. 216.

7 W opublikowanej w 1970 r. Islamskiej Deklaracji A. Izetbegović zawarł idee budowy bałkańskiego państwa muzułmańskiego - zob. D. Wybranowski, Działalność fundamentalistów i ugrupowań islamu radykalnego na obszarze Bałkanów Zachodnich (Bośnia i Hercegowina, Albania, Kosowo, Macedonia) w końcu XX i na poczatku XXI wieku, [w:] Wybrane aspekty bezpieczeństwa, t. II, red. J.J. Piątek, R. Podgórzańska, Szczecin 2007, s. 107. 
dopiero z napływem do Bośni i Hercegowiny mudżahedinów, którzy wzięli udział w wojnie domowej. W latach 1992-1995 bojownicy wywodzący się z różnych islamskich organizacji, w tym uznawanych za terrorystyczne, weszli w skład Armii Republiki Bośni i Hercegowiny (ARBiH), początkowo tworząc odrębne oddziały i pododdziały ${ }^{8}$. Następnie część zagranicznych ochotników szkoliła jednostki bośniackie, inni natomiast służyli w poszczególnych brygadach i korpusach ARBiH, najczęściej tworząc doborowe, szturmowe jednostki sił zbrojnych tego państwa. Znawcy problematyki nie sa pewni, ilu dokładnie „wojowników Allaha" brało udział w tej wojnie. Szacuje się, że liczba zagranicznych ochotników mogła wynosić od kilku do nawet kilkudziesięciu tysięcy ${ }^{9}$.

W serbskiej, jak również zachodniej literaturze przedmiotu, wielokrotnie podkreśla się, że to A. Izetbegović oraz rządząca krajem Partia Akcji Demokratycznej (SDA) sprowadzili mudżahedinów do Bośni i Hercegowiny ${ }^{10}$. „Wojownicy Allaha" przybyli na wezwanie prezydenta, znanego w kręgu islamistów jako Ali Izet (Ali Izaat). Wystapił on z prośbą o ich zwerbowanie do Osamy bin Ladena za pośrednictwem dwóch Sudańczyków: Fatiha al Hasaneina ${ }^{11}$ i Hasana Turabiego,

8 A. Čuvalo, Historical dictionary of Bosnia and Herzegovina, Lanham-MarylandToronto-Plymouth 2007, s. 161-162.

${ }_{9}$ A. Wejkszner, dz. cyt., s. 365. Dragan Džamić obliczył, że na początku 1995 r. zagranicznych ochotników mogło być nawet 15-20 tys. - zob. D. Džamić, dz. cyt., s. 204.

${ }^{10}$ Dž.P. Šindler, Nesveti teror. Bosna, Al Kaida i uspon globalnog džihada, Beograd 2009, s. 108-122 i n.; D. Džamić, dz. cyt., s. 206-207. Dževad Galijašević podkreślił, iż do legitymizacji wstapienia „wojowników Allaha” w szeregi ARBiH doszło 1 sierpnia $1992 \mathrm{r}$. Wówczas, na mocy rozporządzenia prezydenta, weszło w życie prawo o służbie w ARBiH, dzięki któremu w czasie wojny w szeregi armii mogły wstapić osoby nie będące obywatelami państwa bośniackiego. Dž. Galijašević, Era terorizma u BiH, Beograd 2007, s. 111.

${ }^{11}$ Fatih al Hasanein - członek sudańskiego Narodowego Islamskiego Frontu. W 1964 r. przybył do Jugosławii na studia. Dyplom z medycyny zdobył w Belgradzie, natomiast specjalizację internistyczną w Wiedniu. Podczas studiów związał się z A. Izetbegoviciem, to m.in. dzięki jego zaangażowaniu możliwe było opublikowanie Islamskiej Deklaracji. W 1992 r. pełnił funkcję attaché kulturalnego Sudanu w Wiedniu. W 1994 r. w jednym z wywiadów oświadczył, że rozwiązaniem wojny w Bośni powinno być powstanie państwa muzułmańskiego. Założyciel TWRA (Third World Relief Agency), organizacji humanitarnej, która powstała w 1987 r. w Wiedniu. Posiadała kancelarie w Sarajewie, Budapeszcie, Moskwie, Stambule. Faktycznie zajmowała się przestępczą działalnościa, m.in. nielegalnym handlem bronia. W $1993 \mathrm{r}$. Izetbegović przekazał list do jednego z banków austriackich, z którego wynikało, że Fatih al Hasanein posiadał pełne zaufanie władz Bośni. W latach 1992-1995 TWRA dysponowała budżetem ok. 350 mln dolarów, natomiast w sierpniu 1996 r. wynosił on $500 \mathrm{mln}$. Znaczna część tych pieniędzy miała być wykorzystana osobiście przez Izetbegovicia, część natomiast została przeznaczona na uzbrojenie, a jeszcze inna użyta w celu skorumpowania władz w Chorwacji i Słowenii, aby umożliwiły dostawy broni do Bośni. Jak stwierdzili analitycy CIA, po zakończeniu wojny w Bośni Fatih al Hasanein zamierzał finansować islamskich ekstremistów w Mediolanie i Rzymie, aby odnowić siatkę terrorystyczna. Więcej zob.: M. Drecun, dz. cyt., s. 116-118 i n. 
których celem stało się pozyskanie mudżahedinów do prowadzenia „bośniackiego dżihadu"'12.

Najważniejsza siatka przerzutu mudżahedinów (weteranów z Afganistanu) do Bośni działała na linii Wiedeń-Zagrzeb. Następnie dość szybko został otwarty jeszcze jeden kanał, który wiódł przez Włochy (Islamskie Centrum Kultury w Mediolanie). Siatka ta utrzymywała kontakty z bin Ladenem i Ajmanem Az-Zawahirim. W Mediolanie znajdowało się centrum operacji prowadzonych w Bośni, którymi dowodził Anwar Shaban, logistyk Al-Kaidy we Włoszech i uczestnik walk $\mathrm{w}$ Afganistanie, związany z Zawahirim ${ }^{13}$. Jego zadaniem było zebranie ochotników, broni i pieniędzy dla operacji w Bośni, szczególnie w Zenicy. Szlak mediolański, którym byli przerzucani mudżahedini (niektórzy z włoskimi paszportami) wiódł przez Słowenię i Chorwację. Zazwyczaj odbywali oni szkolenie prowadzone przez Shabana w bazie usytuowanej $45 \mathrm{~km}$ od Mediolanu, a następnie udawali się do centralnej Bośni ${ }^{14}$. Ochotnicy przybywali ze wszystkich stron świata, nawet z Polski. Jak dowodził polski kontrwywiad, przywódcami siatki warszawskiej byli uczniowie sarajewskiej medresy Gazi Husrev-bega, propagujący fundamentalistyczną formę islamu ${ }^{15}$.

Warto podkreślić, że prezydent Izetbegović szukał poparcia także wśród szefów rządów muzułmańskich na świecie. Ważną rolę w organizowaniu dżihadu oraz związanej z nią sieci terroru odegrał Iran ${ }^{16}$. W wyniku akcji dyplomatycznej

${ }^{12}$ Dž. Galijašević, dz. cyt., s. 99. Podczas pobytu bin Ladena w Chartumie u Hasana Turabiego, przywódca Al-Kaidy poprosił gospodarza o skontaktowanie go z przywódcami bośniackich Muzułmanów. Współpracownik Turabiego, al Hasanein uchodził za „ministra finansów” A. Izetbegovicia. W samochodzie dyplomatycznym ambasady Sudanu w Wiedniu przewoził do Zagrzebia walizki z pieniędzmi przeznaczonymi dla Muzułmanów w Bośni-zob. E. Hećimović, Garibi. Mudžahedini u BiH 1992-1999, Beograd 2009, s. 35. Wielu polskich znawców tej problematyki podaje natomiast w wątpliwość celowość działań prezydenta A. Izetbegovicia - por. D. Wybranowski, Alija Izetbegović i koncepcja „państwa muzułmańskiego" w Bośni i Hercegowinie w XX wieku (ze szczególnym uwzględnieniem „Deklaracji islamskiej”), „Balcanica Posnaniensia” 2010, t. XVII, s. 162-163 i n.

${ }^{13}$ Anwar Shaban (Enver Šaban) przywódca egipskiej grupy terrorystycznej Gama’at al-Islamiyya, odpowiedzialnej za próbę zamachu na prezydenta Egiptu, Hosniego Mubaraka (26 czerwca 1995 r.). Stał też na czele komórki terrorystycznej w Mediolanie, zbierał środki od włoskich muzułmanów dla uciekinierów w Bośni, które przeznaczał na działalność terrorystyczną w Egipcie. E. Hećimović, $d z$. cyt., s. 87-88. Ponadto jego celem było utworzenie w Bośni sztabu i sieci Al-Kaidy, szczególnie dla członków tej organizacji z północnej Afryki. Więcej na temat działalności Shabana w Bośni: M. Drecun, dz. cyt., s. 94 i n.

${ }^{14}$ Dž.P. Šindler, dz. cyt., s. 150-151. Esad Hećimović wyróżnił dwie fale przybycia mudżahedinów do Bośni: pierwsza w lecie i jesienią 1992 r., natomiast druga w 1994 r. zob. więcej: E. Hećimović, $d z$. cyt., s. 34-35 i n.

${ }_{15}$ Dž.P. Šindler, dz. cyt., s. 191.

16 Między Turcją a Iranem istniała rywalizacja o wpływy polityczne w Bośni i Hercegowinie. D. Džamić, dz. cyt., s. 206. 
podjętej przez A. Izetbegovicia i polityków SDA, Teheran wezwał światową ummę do zjednoczenia się w walce i pomocy bośniackim Muzułmanom, którzy - zdaniem przedstawicieli Iranu - padli ofiara zachodniego spisku. W 1992 r. Haris Silajdžić, bośniacki minister spraw zagranicznych uzyskał w Teheranie obietnicę, że zostanie sformowana armia muzułmańskich ochotników, której celem miało być wsparcie współbraci w Bośni ${ }^{17}$. W latach 1992-1995 r. Iran przekazał $\mathrm{BiH}$ znaczna pomoc finansowa oraz logistyczna - na terytorium tego kraju przerzucono 2 tys. Strażników Rewolucji, którzy weszli w skład jednostek ARBiH w Zenicy. Stworzyli oni oddzielną brygadę, która miała za zadanie wyszkolenie kadr, a także uczestniczenie w najbardziej niebezpiecznych walkach oraz akcjach terrorystycznych. Teheran wysłał również do Bośni 400 oficerów wywiadu, którzy prowadzili instruktaż oraz zajmowali się indoktrynacją ideologiczną. Ponadto w Iranie szkolono setki młodych Bośniaków, którzy po powrocie znaleźli miejsce w „Batalionie wiernych” (Kataeb al Munimin) w okolicach Tuzli oraz działali na terytorium Bužima, gdzie przybyli też ochotnicy z Sudanu, razem 300 osób ${ }^{18}$. W sprawozdaniu Kongresu USA ze stycznia 1997 r. podkreślono, że irańscy Strażnicy Rewolucji szybko integrowali się ze wszystkimi sferami wojskowymi BiH. Irański wywiad VEVAK (Vezarat-e Ettela'at va Amniat-e Keshvar) zorganizował na terytorium całego kraju siatki agencyjne. Irańczycy kontrolowali także znaczną część bośniackiego aparatu bezpieczeństwa. Irańska ambasada pod względem liczby personelu stała się największą w Sarajewie, a jej pracownicy utrzymywali stały kontakt z bośniackimi władzami ${ }^{19}$.

Wśród zagranicznych ochotników znajdowała się też grupa zwolenników Osamy bin Ladena ${ }^{20}$, z którym bezpośrednio współpracował A. Izetbegović. Jak dowodzi Milovan Drecun, celem Al-Kaidy było stworzenie na Bałkanach specjalnej bazy, która umożliwiłaby terrorystom szybsze przedostanie się do Europy Zachodniej. W 1991 r. w Sofii powstało regionalne dowództwo Al-Kaidy, którego celem była organizacja i koordynacja akcji terrorystycznych. Rok później bin Laden postanowił zawrzeć porozumienie z bośniackimi Muzułmanami. Wkrótce zaczęto posyłać przywódcom muzułmańskim w Sarajewie pieniądze, uzbrojenie i grupy ochotników. Wielu członków Al-Kaidy służyło w 7. Brygadzie w Zenicy.

W ocenie serbskiego badacza M. Drecuna, to instruktorzy z tej organizacji terrorystycznej mieli pomóc funkcjonariuszom bośniackich służb specjalnych w przygotowaniu i zrealizowaniu operacji, która doprowadziła do masakry ludności cywilnej na placu targowym Markale ${ }^{21}$. Winę przypisano Serbom, jednym z efektów tej działalności było zaś większe zaangażowanie państw Europy Zachodniej w konflikt w Bośni. John Schindler stwierdził, że Osama bin Laden

\footnotetext{
${ }_{17}$ M. Drecun, $d z$. cyt., s. 79-80.

18 Tamize, s. 81.

19 Tamize, s. 84 .

20 A. Wejkszner, dz. cyt., s. 365.

${ }^{21}$ M. Drecun, $d z$. cyt., s. 100.
} 
kontrolował znaczną część bośniackiego dżihadu, chociaż zwykli żołnierze nie mieli świadomości, kto dowodził operacjami i logistyka oraz jaki był prawdziwy cel prowadzonej wojny ${ }^{22}$. Przywódca Al-Kaidy bez wattpienia przebywał w Bośni i Hercegowinie. Spotykał się także z A. Izetbegoviciem, choć obecne władze bośniackie wypierają się tego, iż miało to kiedykolwiek miejsce ${ }^{23}$. Paszport bośniacki został wydany bin Ladenowi w 1993 r. przez ambasadę Bośni w Wiedniu za pośrednictwem al Hasaneina ${ }^{24}$. W Wiedniu bin Laden pojawił się w towarzystwie tunezyjskiego terrorysty, Adounija Mehreza, który pięć lat później uczestniczył w atakach na amerykańskie ambasady we wschodniej Afryce (Kenia, Tanzania). Funkcję ambasadora pełnił wtedy Husein Živalj (zastępca przewodniczacego TWRA), na decyzji o przyznaniu obywatelstwa BiH podpisał się natomiast Hasan Čengićn ${ }^{25}$.

Zdaniem Rohana Gunaratna, przywódca Al-Kaidy przebywał w Bośni na przełomie 1992 i 1993 r., kiedy ta organizacja terrorystyczna organizowała w okolicach Tuzli szkolenia dla zagranicznych ochotników, wręczony mu paszport miał zaś stanowić dowód wdzięczności politycznej elity kraju za wsparcie udzielone bośniackim Muzułmanom ${ }^{26}$.

W Sarajewie bin Laden pojawił się w 1994 r. Najbardziej wiarygodnym świadkiem tego zdarzenia była Renate Flottau, ceniona dziennikarka „Der Spiegela”, która spotkała tego „sławnego” terrorystę w 1994 r. (nie pamięta dokładnej daty) przed gabinetem prezydenta A. Izetbegovicia. Dał jej wówczas swoja wizytówkę, lecz jego nazwisko nie było znane dziennikarce. Rozmawiali przez krótki czas, zwróciła uwagę na jego doskonała angielszczyznę; w czasie tej rozmowy przywódca Al-Kaidy przyznał, że przebywał w Bośni w celu sprowadzenia na jej terytorium zagranicznych ochotników ${ }^{27}$.

${ }^{22} \mathrm{~W}$ ocenie J. Schindlera, spośród organizacji terrorystycznych Al-Kaida odegrała dominująca rolę w bośniackiej wojnie domowej, badacz ten natomiast mniejsze znaczenie przypisuje Hezbollahowi, który także wysyłał instruktorów do Bośni. Dž.P. Šindler, dz. cyt., s. 111. Z kolei M. Drecun podkreślił, że Al-Kaida finansowała akcje terrorystyczne za pośrednictwem 40 organizacji humanitarnych. Wiele spośród nich prowadziło działalność w Bośni i Hercegowinie, Albanii, Macedonii i Kosowie, chociaż siatki terrorystyczne powstające wówczas na terytorium Bośni w większym stopniu były organizowane przez amerykański i irański wywiad, natomiast Al-Kaida i bin Laden odgrywali drugorzędną rolę. Więcej zob. M. Drecun, dz. cyt., s. 84, 99-115 i n.

${ }^{23}$ W literaturze przedmiotu kontrowersje wokół pobytu bin Ladena w Bośni często doprowadzają do sprzecznych konkluzji i braku jednoznacznego stanowiska w tej sprawie. D. Wybranowski, Alija Izetbegović..., s. 161.

${ }^{24}$ D. Džamić, $d z$. cyt., s. 255; natomiast M. Drecun stwierdził, że dokumenty świadczące o pobycie bin Ladena w Sarajewie zostały celowo zniszczone, aby zatrzeć po nim wszelkie ślady - zob. M. Drecun, dz. cyt., s. 130.

25 M. Drecun, dz. cyt., s. 129.

${ }^{26}$ R. Gunaratna, Inside Al Qaeda. Global network of terror, New York 2003, s. 176.

27 Dž.P. Šindler, dz. cyt., s. 115. Podobną relację ze spotkania R. Fllotau z bin Ladenem przedstawił M. Drecun, uzupełniając ją o szczegóły, z których wynikało, iż jeden 
Istotnym świadkiem pobytu bin Ladena w Sarajewie była także brytyjska dziennikarka Eve Ann Prentice, która w lutym 2006 r. przed Międzynarodowym Trybunałem Karnym dla byłej Jugosławii w Hadze zeznała pod przysięga, że w 1994 r. widziała w Sarajewie lidera Al-Kaidy, który czekał na spotkanie z A. Izetbegoviciem w budynku Prezydium $\mathrm{BiH}^{28}$.

Koordynacja działań muzułmańskich jednostek walczących na terytorium Bośni i Hercegowiny odbywała się poprzez otwarte w 1991 r. w Sofii biuro Ajmana Az-Zawahiriego, dzięki któremu mógł on nadzorować prowadzenie operacji terrorystycznych w Bośni. Bliski kręgom policji tygodnik „Slobodna Bosna” uzyskał informację, że w 1993 r. Zawahiri wizytował 3. Korpus ARBiH w Zenicy, wtedy też spotkał się z Izetbegoviciem. Związki z Al-Kaidą utrzymywał także Mehmed Alagić, dowódca 3. Korpusu (a następnie 7. Korpusu). Podejrzewano go, że otrzymywał znaczne kwoty od tej organizacji terrorystycznej. Z bin Ladenem natomiast był związany samodzielny batalion „Ansar”, działający na terytorium Travnika i Zenicy, który miał swoją bazę w Pakistanie ${ }^{29}$.

W ocenie wielu bałkanistów, A. Izetbegović był „najważniejszym bośniackim islamista, który uczestniczył w tworzeniu w Bośni bazy globalnego dżihadu". Jako dowód często przedstawiane są dokumenty niemieckiej kancelarii Interpolu w Wiesbaden oraz oddziału zwalczającego terroryzm w austriackim ministerstwie spraw wewnętrznych. Śledztwa w tej sprawie były prowadzone w latach 1995-1996 i nagle zostały przerwane, a dokumenty utajniono na żądanie wysokiego funkcjonariusza niemieckiego wywiadu $\mathrm{BND}^{30}$. W ocenie J. Schindlera, bośniacka elita władzy wspierała powołanie do życia minipaństwa islamskiego w centralnej Bośni, podobnie jak islamiści w czasie II wojny światowej, którzy

z doradców prezydenta tłumaczył, że A. Izetbegović nie chciał mieć nic wspólnego z przywódcą Al-Kaidy, ale następnego dnia dziennikarka ponownie spotkała przed jego gabinetem bin Ladena - zob. M. Drecun, dz. cyt., s. 129. W kontekście tych informacji potwierdzonych przez świadków należy podać w wątpliwość opinię bośniackiego dziennikarza E. Hećimovicia, który uznał, że nie ma dowodów przemawiających za pobytem bin Ladena w Bośni - por. E. Hećimović, dz. cyt., s. 142.

${ }^{28}$ Kiedy Eve Ann Prentice w Hadze potwierdziła, iż spotkała bin Ladena w Sarajewie, sędzia przerwał jej zeznanie, ogłosiwszy, że jest ono nieistotne - zob. Dž.P. Šindler, dz. cyt., s. 296. Zdarzenie to dowodzi, że często oskarżany o stronniczość Trybunał w Hadze potwierdził, iż wątpliwości co do jego obiektywizmu nie są pozbawione racji. Opierając się zatem na relacji brytyjskiej dziennikarki, można stwierdzić, że niewygodne fakty, mogące świadczyć niekorzystnie o polityce państw zachodnich, które tolerowały związki elit bośniackich z międzynarodowym terroryzmem, są skutecznie tuszowane przez osoby, które na mocy prawa międzynarodowego zostały upoważnione do wyjaśnienia tragicznych wydarzeń w byłej Jugosławii.

${ }_{29}$ M. Drecun, dz. cyt., s. 130.

${ }^{30}$ Tamże, s. 150. O powiązaniach mudżahedinów walczących w Bośni z amerykańskimi i niemieckimi służbami specjalnymi więcej zob.: J. Elsässer, Jak dżihad przybyt do Europy. Wojownicy Boga i tajne stużby na Bałkanach, Warszawa 2007, s. 229-247 i n. 
dążyli do uzyskania statusu satelity III Rzeszy. Oczywiście, surowo osądzając elity polityczne nie można odnosić się tak do wszystkich bośniackich Muzułmanów, spośród których część nie popierała polityki SDA, a władzę w Sarajewie uważała za skorumpowaną i fanatyczna ${ }^{31}$. Wpływowy polityk i biznesmen Fikret Abdic $^{32}$ wyraził pogląd, że „Izetbegović jest przebiegłym oszustem i największym morderca swojego narodu. Nigdy nie zapomniał o ideach zawartych w Islamskiej Deklaracji, czyli stworzeniu z Bośni państwa islamskiego" ${ }^{33}$. W literaturze przedmiotu, do której odwołuje się autorka niniejszego artykułu, w sposób wyraźny wyłania się, bez cienia wątpliwości, mroczny obraz prezydenta A. Izetbegovicia jako skorumpowanego polityka, dążącego do budowy państwa islamskiego, nie wahającego się użyć do tego celu terroru państwowego ${ }^{34}$.

\section{Plan „Bałkany 2020” - rekrutowanie na Bałkanach „Białej Al-Kaidy”}

Po zakończeniu wojny domowej w Bośni znaczna liczba mudżahedinów została skierowana na inne fronty: do Czeczenii czy Kosowa, część spośród nich natomiast pozostała na miejscu, gdzie „serce islamizmu” stanowił obóz w miejscowości Donja Bočinja, w którym schronienie znaleźli m.in. weterani z oddziału

${ }^{31}$ Dž.P. Šindler, dz. cyt., s. 211-217.

32 Fikret Abdić (ur. 1934 r.) - polityk i biznesmen, znany pod pseudonimami „Dad$d y$ ”,,Babo". Przed wojną domową osoba wpływowa, przez 20 lat był dyrektorem „Agrokomercu" z siedzibą w miejscowości Velika Kladuša, jednego z największych zakładów przemysłu spożywczego w Jugosławii. W 1987 r., kiedy zarządzane przez niego przedsiębiorstwo zbankrutowało, został oskarżony wraz z kierownictwem o spowodowanie finansowego nadużycia i uwięziony. Udało mu się jednak utrzymać popularność w regionie. W $1990 \mathrm{r}$. w wyborach prezydenckich zyskał więcej głosów niż A. Izetbegović, ale z nieznanych powodów zrezygnował z urzędu. W 1993 r. proklamował Autonomiczną Prowincję Zachodniej Bośni. W zarządzanym przez siebie regionie współpracował z Serbami, był też zwolennikiem pluralistycznej i multikulturowej Bośni, jak również oponentem radykalnego islamu. Po wojnie, dzięki prezydentowi Franjo Tuđmanowi, otrzymał azyl polityczny oraz obywatelstwo Chorwacji. W 2001 r. został jednak aresztowany przez władze chorwackie, oskarżony o zbrodnie wojenne w okręgu Bihać i skazany na 20 lat więzienia. W 2002 r. ubiegał się o prezydenturę podczas wyborów w Bośni, zdobywając 4,1\% głosów. W 2005 r. wyrok został zmniejszony do 15 lat-por. A. Čuvalo, $d z$. cyt., s. 1-2. Spodziewany jest jego powrót do polityki po warunkowym wyjściu z więzienia 9 marca 2012 r. Nermin Purić: Fikret Abdić ne ma ograničenja da uđe u politiku, 8 III 2012, http://www.kip.ba/2012/03/08/ nermin-puric-fikret-abdic-nema-ogranicenja-da-ude-u-politiku/ (dostęp 8 III 2012).

33 „Večernji list”, 21 IX 1993; Dž.P. Šindler, dz. cyt., s. 188.

${ }_{34}$ Słuszna wydaje się hipoteza, że władze bośniackie stosowały terror przy tworzeniu oficjalnej państwowej strategii, która miała na celu budowę jedynej, muzułmańskiej Bośni. D. Gibas-Krzak, Terroryzm i radykalny islam..., s. 21. 
„El Mudžahedin”35. Ochotnicy z tego obozu znani byli np. z napadu na norweskiego gen. Kjella Grandhagena, byłego dowódcę brygady SFOR ${ }^{36}$.

W połowie listopada $1995 \mathrm{r}$. kilkudziesięciu wyższych islamskich dowódców spotkało się w Sofii, aby omówić przygotowania do nowych operacji terrorystycznych po zawarciu porozumienia w Dayton i rozmieszczaniu żołnierzy IFOR w Bośni. Na początku maja 1996 r. siły islamistyczne były gotowe do podjęcia kolejnych akcji. Zaczęła bowiem działać nowa grupa uderzeniowa terrorystów - samobójców, gotowych umrzeć w imię Allaha, składająca się z młodych Bośniaków o jasnych włosach. Naśladowali oni terrorystów z Bliskiego Wschodu, zostali wyszkoleni w operowaniu materiałami wybuchowymi oraz prowadzeniu samobójczych misji. Liderzy i komendanci Al-Kaidy postanowili bowiem rekrutować nowych terrorystów spośród Słowian, tworząc „Białą Al-Kaidę”, trudniejszą do zidentyfikowania. Stworzono nazwę „Bałkańczycy” dla weteranów wojny domowej w Bośni, którzy mieli być groźniejsi od uczestników wojny w Afganistanie. W tym samym roku współpraca Teheranu i Sarajewa doprowadziła do dalszego rozwoju baz terrorystycznych na Bałkanach ${ }^{37}$.

W centralnej Bośni po zakończeniu wojny działała Takfir wal Hidżra (Klątwa i Wygnanie), egipska organizacja terrorystyczna, związana z bin Ladenem, której celem było prowadzenie dżihadu przeciwko niewiernym. Wiele danych na jej temat pozostaje tajnych, choć informacje o niej były znane dowództwu 3. Korpusu. Po przybyciu do Bośni główną rolę odgrywał w niej Abu Hamza al Misri, zwany jako Abu Kuka. Działała na obszarze Vitez-Busovača-Kakanj-Visoko. Była odpowiedzialna za wszystkie akcje terrorystyczne prowadzone od $1996 \mathrm{r}$. w centralnej Bośni ${ }^{38}$. Jej członkowie popełnili wiele zbrodni wojennych, zwłaszcza wobec chorwackich i serbskich cywili oraz wziętych do niewoli żołnierzy ${ }^{39}$. W styczniu 1996 r. islamscy terroryści, którzy szkolili się w Zenicy, związani

35 „El Mudžahedin”, szturmowa jednostka złożona z zagranicznych ochotników, biorących udział w wojnie domowej w Bośni, od sierpnia $1993 \mathrm{r}$. formalnie w składzie ARBiH. Znana ze zbrodni wojennych popełnionych na Serbach oraz ludności cywilnej. Zgodnie z poufnymi dokumentami z listopada 1995 r., na czele oddziału znajdował się emir Abu Maali Hasan, ideologiem zaś był Anwar Shaban. Oddział „El Mudžahedin” miał swoich przedstawicieli w Zagrzebiu oraz Splicie. W Zagrzebiu organizowano dla niego pomoc logistyczną oraz przerzut mudżahedinów z Chorwacji do Bośni. M. Drecun, dz. cyt., s. 134.

${ }^{36}$ D. Džamić, $d z$. cyt., s. 256-257.

${ }^{37}$ Francuska agencja AFP, powołując się na źródła wywiadowcze w Sarajewie, w listopadzie 2004 r. informowała, że celem fundamentalistów jest rekrutowanie terrorystów o jasnych włosach i z jasnymi oczami, którzy mieli być mniej podejrzani. M. Drecun, dz. cyt., s. 305 i n.

38 Tamże, s. $136-137$.

39 Fanatycy z tej organizacji w 1995 r. próbowali nawet zgładzić bin Ladena, gdyż ich zdaniem nie był zbyt pobożnym muzułmaninem, Klatwa nad Europa, 15 II 2005, http:// www.newsweek.pl/wydania/697/klatwa-nad-europa,18077,1,1 (dostęp 12 II 2012). 
z Takfir wal Hidżra (m.in. Christoph Caze, Lionel Dumont) zorganizowali we Francji siatkę terrorystyczna, zwaną grupa z Roubaix, która napadała na supermarkety i furgonetki bankowe ${ }^{40}$.

W ocenie Artura Wejksznera, po 1995 r. działalność dżihadystów na terytorium Bośni uległa osłabieniu z powodu zintensyfikowania akcji antyterrorystycznych przez USA ${ }^{41}$. Nie można jednak bagatelizować tego zjawiska, w XXI w. doszło bowiem do odradzania się na Bałkanach sieci terrorystycznej, związanej z muzułmańskim fundamentalizmem. W połowie 2003 r. radykalni islamistyczni liderzy zaplanowali zbudowanie terrorystycznej infrastruktury na terytorium Bałkanów, aby rozszerzyć dżihad na cała Europę. Przyjęto plan „Bałkany 2020”, autorstwa Ajmana Az-Zawahiriego ${ }^{42}$, w którym Bałkany stanowia jedno z centrów islamskiego terroryzmu w Europie, odgrywając zarazem kluczową rolę w strategii Al-Kaidy przyjętej do 2020 r., dotyczącej Bośni i Hercegowiny, Kosowa, Sandżaku i Chorwacji. Na tych terytoriach formowane są bowiem centra służące do rekrutowania terrorystów. Ponadto jednym z założeń strategii jest tworzenie ośrodków służących szerzeniu ideologii fundamentalistycznej i terroryzmu w Zachodniej Europie, szczególnie we Włoszech i w Hiszpanii. Elementem planu jest również organizowanie szkół, meczetów i islamskich instytucji (ośrodków naukowych, kulturalnych, organizacji humanitarnych) za środki płynące z Arabii Saudyjskiej w celu kształcenia społeczeństwa w duchu radykalnego islamu. W strategii „Balkany 2020" istotne znaczenie ma także przestępczość zorganizowana, przede wszystkim handel narkotykami, który służy finansowaniu akcji terrorystycznych. Terroryści, wykorzystując Bałkany, doskonalą swój system logistyczny, tak aby móc szybko przesyłać ludzi, broń i pieniądze na Zachód Europy, jak również do Iraku ${ }^{43}$. Jednym z zasadniczych celów w ramach przyjętej strategii jest więc wzmocnienie akcji w Europie Zachodniej poprzez rekrutowanie mieszkańców Bałkanów oraz ich szkolenie i przygotowanie do uderzeń terrorystycznych. Zadanie to otrzymał Musa Ajzi, który zajmował się werbunkiem „Białej Al-Kaidy” z Bośni i Sandżaku. Już pod koniec sierpnia 2003 r. udało mu się zebrać grupę ochotników, pochodzących ze słowiańskiej grupy etnicznej, głównie z Kosowa i Bośni, którą nazywał „białymi diabłami”. Ocenił, że sa zdolni do akcji samobójczych w całej Europie, a także w Izraelu. Szkolenie ich odbywało się na Bałkanach, na Kaukazie i w Gruzji. Swoistą „trampoliną”

${ }^{40}$ O losach terrorystów z grupy Roubaix więcej u: Dž.P. Šindler, dz. cyt., s. 194-195, 205-206 i n.

${ }^{41}$ A. Wejkszner, $d z$. cyt., s. 368.

${ }^{42}$ Ten przywódca Al-Kaidy już w 1995 r. domagał się zwiększenia liczby placówek terrorystycznych na Bałkanach, które miały doprowadzić do umacniania się ruchu fundamentalistycznego w Europie w ramach globalnej sieci dżihadu. Y. Bodansky, Osama bin Laden. Człowiek, który wypowiedziat wojnę Ameryce, Warszawa 2001, s. 95.

${ }^{43}$ M. Drecun, $d z$. cyt., s. 6-9, 305 i n. 
do przenoszenia nowej fali terroryzmu miały stać się także Albania, Kosowo, Macedonia, gdzie również prowadzono werbunek terrorystów, którzy mieli zostać wykorzystani w porozumieniu z Al-Kaidą do akcji na Zachodzie. W okolicy Zenicy powstało kilka centrów szkolenia, a wahhabici utworzyli swoją bazę niedaleko Maglaja i Bihacia ${ }^{44}$.

W 2004 r. terroryści na Bałkanach rozpoczęli kolejny etap rozwoju sieci globalnego dżihadu. Albańscy ekstremiści i fundamentaliści islamscy porozumieli się bowiem, aby wspólnie szkolić ochotników, którzy wzięliby udział w akcjach samobójczych na całym świecie. Pochodzili oni z Kosowa, Sandżaku, Macedonii, Albanii oraz południowej Serbii. Planowano przygotować 1,5 tys. samobójców, którzy mieli podpisać umowę z Al-Kaidą. Do końca 2004 r. wyszkolono około 200 terrorystów w wieku 20-25 lat. Instruktaż odbywał się w krajach islamskich, a za ich naukę płacił oddział Al-Kaidy odpowiedzialny za Bałkany i Europę. Następnie zostali oni rozmieszczeni głównie na terytorium Macedonii i Kosowa. W 2005 r. szkolenie samobójców kontynuowano na północy Albanii i w Kosowie, rekrutowano tam m.in. kobiety, wybrane spośród wdów, które na wojnie straciły rodziny, przekonywano je, że „powinny oddać dusze Allahowi i Wielkiej Albanii”. Centra szkoleniowe znajdowały się w obozach Wyzwoleńczej Armii Kosowa $(\mathrm{UCCK})^{45}$, które funkcjonowały pod protektoratem albańskiego premiera Sali Berishy. Na terytorium Kosowa, w trudno dostępnych górach, tuż przy granicy z Albanią umieszczono obóz, gdzie szkolono 10 samobójczyń. Ćwiczenia prowadzili brytyjscy instruktorzy, specjaliści od materiałów wybuchowych, którzy od 1998 r. znajdowali się na liście płac mafii albańskiej. Po zakończeniu instruktażu przyszłe samobójczynie powracały do swoich miejsc zamieszkania i tam zostawały swoistymi „terrorystycznymi śpiochami”" ${ }^{\prime 6} \mathrm{Al}-\mathrm{Kaidy}^{47}$.

${ }_{44}$ Tamize, s. 304-305.

${ }^{45}$ UÇK - militarna organizacja albańskich separatystów utworzona w 1992 r. Do końca 1997 r. nie miała dokładnego planu działania, dokonując napadów na serbskie posterunki policji i zastraszając Albańczyków, którzy współpracowali z Serbami. Stosując metody terrorystyczne, dążyła do umiędzynarodowienia kosowskiego konfliktu i przekonania mocarstw, a zwłaszcza USA, do opowiedzenia się po stronie Albańczyków. Początkowo USA twierdziły, że jest to organizacja terrorystyczna, dopiero po $1998 \mathrm{r}$. Waszyngton zmienił do niej stosunek, uznając jej członków za bojowników walki o niepodległość. Więcej zob. D. Gibas-Krzak, Serbsko-albański konflikt o Kosowo w XX wieku. Uwarunkowaniaprzebieg - konsekwencje, Toruń 2009, s. 177-181 i n.

46 „Śpioch”, inaczej agent „uśpiony”, „zamrożony”, jest to agent wywiadu, rzadziej kontrwywiadu, który nie prowadzi aktywnej działalności, może jednak na nowo podjać pracę na sygnał z centrali, często zdarza się to jednak dopiero po wystapieniu szczególnych okoliczności, np. powstania nadzwyczajnej sytuacji politycznej - zob. Polskie służby specjalne. Stownik, pod red. K.A. Wojtaszczyka, Warszawa 2011, s. 202-203. W tym przypadku mamy do czynienia z przeszkolonym terrorysta, który oczekuje na sygnał do działania, podobnie jak „uśpiony” agent wywiadu.

${ }^{47}$ M. Drecun, dz. cyt., s. 300. 
Należy podkreślić, że rekrutowanie „Białej Al-Kaidy” skończyło się sukcesem, co potwierdziły śledztwa policji oraz służb specjalnych. Według oceny wywiadu amerykańskiego, w 2004 r. na terytorium Albanii, Bułgarii, Macedonii, Kosowa, Bośni i Hercegowiny około 6 tys. ludzi utrzymywało pośrednią i bezpośrednią więź z Al-Kaidą. Aresztowani w 2005 r. członkowie wahhabickiej grupy terrorystycznej z wioski Gorna Maoča (niedaleko miasta Brčko) przyznali, iż zamierzali przeprowadzić atak bombowy na Watykan. Ich przywódca Enes Mujkanović, zwany Abu Omar Al Kadab, wyjawił w wywiadzie dla chorwackiego pisma „Večernji list”, że „przygotowywane są wojska Allaha, aby iść na Rzym i tam zadać klęskę chrześcijanom". Angielskie jednostki antyterrorystyczne, które przebywały w Sarajewie wykryły związki między terrorystami, którzy podłożyli bomby w Londynie 7 lipca 2005 r., a terrorystami bośniackimi. Za kolebkę terroryzmu został uznany sarajewski meczet króla Fahda, gdzie m.in. znajdują schronienie ekstremiści z Wielkiej Brytanii.

W 2005 r. w wyniku śledztw policji duńskiej i bośniackiej zatrzymano członków „Grupy sarajewskiej”, która była wyposażona w bomby i detonatory ${ }^{48}$. Rozbita została także terrorystyczna grupa „Maksimus”, działająca w kantonie Sarajewo. Znaleziono dowody, iż w wrześniu 2005 r. powstała komórka Al-Kaidy na północną Europę. Przywódca tej grupy nazywał się Mirsad Bektašević, był to 19-latek ze szwedzkim paszportem, znany jako cyberterrorysta, który przez Internet kontaktował się z przywódcą Al-Kaidy w Iraku, Abu Musabem Al Zarkawim. Jego zadaniem było rekrutowanie przez Internet młodych muzułmanów do siatki bin Ladena ${ }^{49}$.

W 2007 r. chorwacki wywiad uzyskał informacje, że tworzenie sieci „Białej Al-Kaidy" jest prowadzone od czterech lat, i to nie tylko w Bośni, gdyż w 2006 r. siatki terrorystyczne odkryto w rumuńskim mieście Temiszwar, gdzie ujawniono działalność członków Bractwa Muzułmańskiego. Zgodnie ze źródłami serbskimi, zagrożenie stanowi także organizacja „Vehabis”, powiązana z Hamasem, której członkami są wahhabici z Mostaru, Bihacia, Travnika, Zenicy i Teslicia. Zajmują się oni organizacją zakupu i transportu broni do jednostek terrorystycznych w Europie. Posiadają także wpływy wśród muzułmańskich działaczy partii politycznych w Serbii, Czarnogórze i Chorwacji. Agenci wywiadu USA zidentyfikowali na Bałkanach kilka grup terrorystycznych, w tym Al-Kaidy, wśród wspólnot muzułmańskich w Albanii, Bośni, Kosowie, Macedonii. Szczególnie

${ }^{48}$ Tami்e, s. 300-307.

49 W latach 2004-2005 „Maximus”, przy pomocy znanego hakera, islamisty z Wielkiej Brytanii, zebrał grupę ok. 40 osób, pochodzących z Bośni, Wielkiej Brytanii, Bangladeszu, Danii, Szwecji, Kanady i Turcji, które osobiście się nie znały. Terroryści rekrutowani przez Internet planowali ataki na wiele obiektów rządowych i użyteczności publicznej, m.in. w Bośni i Kanadzie. J. Adamski, Nowe technologie w służbie terrorystów, Warszawa 2007, s. 155. 
region Bihacia w Bośni jest znany jako koncentracja wahhabitów, popierających Al-Kaide $e^{50}$, gdzie - jak już stwierdzono - werbowano terrorystów ze słowiańskiej grupy etnicznej, tworząc struktury „Białej Al-Kaidy”.

\section{Rozwój sieci globalnego dżihadu na Bałkanach w wieku XXI}

W ocenie wielu badaczy serbskich, regionalna terrorystyczna sieć na Bałkanach nadal się umacnia. Rozszerza ona swoje wpływy na terytorium Sandżaku, Kosowa, Bośni, Macedonii oraz Albanii. Radykalizuje się, tworząc parawojenne struktury, współpracuje także z Al-Kaidą i innymi organizacjami ekstremistycznymi oraz terrorystycznymi. Działalność ta jest koordynowana z Wiednia, gdzie Muhamed Porča zajmuje się finansowaniem terrorystów związanych z radykalnym islamem. Jednym z pierwszych jej celów jest autonomia Sandżaku, którego system prawny miałby być oparty na zasadach szariatu. Kolejnym jest doprowadzenie do stworzenia bazy dżihadu na Bałkanach. Przy czym główną część tej bałkańskiej terrorystycznej siatki stanowi struktura wahhabijska na południu Serbii (Preševo, Bujanovac). Na tym terytorium komórki związane z fundamentalistycznymi odmianami islamu znajdują się prawie w każdej albańskiej wiosce. Większość młodych hodżów prowadzi indoktrynację zgodnie z zasadami pojmowania islamu w doktrynie wahhabitów. W Bujanovcu działa także sekta salafitów ze sztabem w Uroševacu (Kosowo). Współpracuje ona z mudżahedinami, którym daje schronienie, ponadto rekrutuje oraz szkoli młode osoby w zakresie posługiwania się materiałami wybuchowymi. Terroryści - wahhabici docieraja także do Belgradu, Nišu, jak również Nowego Sadu. Na temat radykalnego islamu w Czarnogórze jest najmniej danych, gdyż władze często neguja istnienie fundamentalnych nurtów tej religii albo pomniejszają ich znaczenie ${ }^{51}$.

Darko Trifunović z Uniwersytetu w Belgradzie, jeden z ekspertów ds. terroryzmu i jego zwalczania, twierdzi, że to Serbia stanowi obecnie centrum szkoleniowe siatki terrorystycznej, która swoimi wpływami obejmuje nie tylko Bałkany, ale i całą Europę. Członkowie radykalnych grup muzułmańskich aktywnie działają w Bośni i Kosowie. Zajmuja się propagowaniem fundamentalizmu w wielu instytucjach i medresach. Biora również udział w życiu ekonomicznym, dysponując kontami w bankach: BBI Bank (Bosna Bank International) oraz Hypo-Alpe-Adria d.d. Mostar. Różne organizacje charytatywne stanowią także czesść tej sieci, np. BIF z Sarajewa (Benevolence International

\footnotetext{
${ }^{50}$ M. Drecun, $d z$. cyt., s. 309.

51 Tamże, s. 296.
} 
Foundation $^{52}$ ) czy też Furgan e-Taibah International z Travnika ${ }^{53}$. Używając różnych zagranicznych korporacji, zarejestrowanych na Cyprze, Brytyjskich Wyspach Dziewiczych, Słowacji oraz w Czechach zajmują się eksportowaniem broni i amunicji, wyposażając Hamas, Hezbollah oraz inne organizacje terrorystyczne. W tym „biznesie” bierze aktywny udział wielu polityków kosowskich i bośniackich, np. Hasan Čengić, Haris Silajdžić czy Hasim Thaçi.

Zdaniem D. Trifunovicia, fundamentalizm islamski niesie szczególne zagrożenie dla bezpieczeństwa, czego przykładem może być atak na ambasadę USA w Sarajewie, dokonany przez Mevlida Jašarevicia (28 października 2011 r.) pod hasłem zemsty za Muammara Kaddafiego ${ }^{54}$. Serbska opinia publiczna uznała, że wahhabici moga przygotowywać podobne akcje w Kosowie, czemu sprzyja postawa społeczności międzynarodowej, która nie potrafiła wymusić na władzach bośniackich, aby usunęły z Bośni członków Al-Kaidy, uczestników wojny domowej ${ }^{55}$. W marcu 2011 r. zamachowiec z Sarajewa przebywał w miejscowości Gorna Maoča, w domu Nusreta Imamovicia, lidera salafitów. Brał udział w prowadzonych przez niego zajęciach szkoły zimowej, podczas których większość uczestników stanowili Serbowie ${ }^{56}$.

Dževad Galijašević podkreślił, że na Bałkanach można oczekiwać kolejnych, bardziej radykalnych aktów terroru, skierowanych przeciwko misjom

${ }^{52}$ BIF z siedzibą w Illinois powstała w latach 80. XX w. Pod przykryciem organizacji humanitarnej zajmowała się gromadzeniem środków potrzebnych do prowadzenia dżihadu w Afganistanie. Na początku lat 90. (pod przywództwem Saudyjczyka, Adel Abdul Jalil Baterjee) celem jej działalności stała się Bośnia. Organizacja przesyłała na potrzeby zagranicznych ochotników w tym kraju środki finansowe w wysokości milionów dolarów, które oficjalnie zostały zebrane, aby wspierać uciekinierów i sieroty wojenne. Dž.P. Šindler, dz. cyt., s. 147-148, 264-266. Jednym z działaczy BIF był współpracownik bin Ladena, Enam Arnaut, syryjski islamista, albańskiego pochodzenia. W 2002 r. w wyniku działań FBI kancelaria BIF w Illinois została zamknięta, a Arnaut osądzony na 11 lat więzienia za pomoc terrorystom. Po wydaniu wyroku na Arnauta, organizacja ta zaprzestała działalności, ale wkrótce powstał nowy BIF, pod nazwa „Bośniacka Idealna Przyszłość”, z siedzibą w Sarajewie, którego celem stała się kontynuacja rozpoczętych „programów humanitarnych" BIF, szefem został zaś zaufany A. Izetbegovicia, Munib Zahiragić, członek wywiadu muzułmańskiego - zob. M. Drecun, dz. cyt., s. 107.

${ }^{53}$ D. Trifunović, Dž. Galijašević, Terrorism in the Western Balkans: between transition and radicalism (mps artykułu udostępniony autorce), 30 X 2011, s. 2.

${ }^{54}$ Najważniejszym celem ataku tego wahhabity było zostanie szehidem, męczennikiem, który zyskałby nagrodę w raju, ginąc $\mathrm{w}$ walce $\mathrm{z}$ niewiernymi. Władze zatrzymały także dwóch wspólników Jašarevicia, bośniackich wahabitów - Dino Pečenkovicia i Muniba Ahmetspahicia. Zob. S. Mišljenović, Vehabija iz Novog Pazara pucao na ambasadu SAD, 28 X 2011, http://www.novosti.rs/vesti/planeta.70.htm (dostęp 12 II 2012).

55 Tamize.

${ }^{56}$ Islamski teror iz bečke Sahab džamije, 31 X 2011, http://www.vesti-online.com/ Vesti/Ex-YU/175704/Islamski-teror-iz-becke-Sahab-dzamije (dostęp 12 II 2012). 
dyplomatycznym USA, bazom NATO czy też siłom zbrojnym Bośni i Hercegowiny, bioracym udział w operacjach poza granicami kraju. Ekspansja ruchu wahhabitów w tym kraju jest możliwa dzięki poparciu udzielonemu temu nurtowi przez religijnych i politycznych liderów w Sarajewie oraz aprobacie Zachodu, zwłaszcza USA, które swoja politykę w regionie opierają na politycznym micie serbskiej winy, co sprzyja rozwojowi fundamentalizmu i związanego z nim terroryzmu. Atak wahhabity w Sarajewie uzmysłowił Bośniakom, że terroryści maja zamiar intensyfikować swoje akcje, skracając czas między nimi. Ponadto ich ataki mogą wiązać się z coraz większą liczbą ofiar i zniszczeń ${ }^{57}$.

W ocenie Dž. Galijaševicia, centrum wahhabizmu na Bałkanach znajduje się nie w Sandżaku, Kosowie czy Czarnogórze, ale w Sarajewie ${ }^{58}$. Natomiast D. Trifunović podkreślił, że Bośnia nie stanowi tylko bazy terrorystów, lecz kraj ten stał się „fabryką do produkcji terrorystów” 59 . Trudno nie przyznać racji temu ekspertowi, który wielokrotnie podkreślał, że opinia publiczna na Zachodzie prawie wcale nie zwróciła uwagi na fakt, że uczestnicy zamachów z 11 września walczyli w wojnie domowej w Bośni i posiadali obywatelstwo bośniackie (Khaled Shayh Mohammed, Remzi Bin-al-Sibih, Mohammed Atta, Khalid al Midhar, Ziyad Yarah, Hani Hanyour czy Nawaf al-Hazmi) ${ }^{60}$. Nadal akty terrorystyczne, do których dochodzi w Bośni, traktowane sa prawie jako political fiction, zajmuja w mediach niewiele miejsca, pozostając tam najwyżej dzień lub dwa, gdy tymczasem śledztwa mogłyby zaprowadzić do firmy MPRI (Military Professional Resources Inc. $)^{61}$, która szkoliła bośniacką armię oraz organizowała „import” afgańskich mudżahedinów.

Spośród znawców problematyki terroryzmu na Bałkanach istotne wydaja się także poglądy Avigdora Liebermana, ministra spraw zagranicznych Izraela,

${ }^{57}$ Do ostatniego ataku, przed ostrzelaniem ambasady przez Jašarevicia, doszło 27 czerwca 2010 r. w Bugojnie (centralna Bośnia). Wówczas w wyniku eksplozji bomby dokonanej przez muzułmańskich fundamentalistów przed posterunkiem policji zginął jeden funkcjonariusz, a pięciu zostało rannych - zob. Atak na posterunek policji w Bośni, 27 VI 2010, http://www.studium.uw.edu.pl/?old/bis8-314 (dostęp 12 II 2012).

${ }^{58}$ Bosnian Wahhabis aim for additional base, 6 I 2010, http://serbianna.com/news/ archives/3785 (dostęp 12 II 2012).

${ }_{59}$ Specijalci češljaju Maglaj u potrazi za vehabijama, 2 XI 2011, http://www. blic.rs/Vesti/Hronika/287028/Specijalci-cesljaju-Maglaj-u-potrazi-za-vehabijama (dostęp 12 II 2012).

${ }^{60}$ D. Trifunović, Dž. Galijašević, dz. cyt., s. 11.

${ }^{61}$ MPRI - amerykańska firma zajmująca się m.in. organizowaniem szkoleń wojskowych, jak również nieoficjalnie werbunkiem najemników, założona w 1987 r. przez emerytowanych oficerów amerykańskich. W 1994 r. specjaliści z MPRI zawarli z rządem Chorwacji umowę o doradztwie w zakresie szkolenia armii, natomiast przed rozpoczęciem operacji „Burza” szef MPRI odbywał narady z dowódcami armii chorwackiej, w tym także z gen. Varimarem Cervenko, który zaplanował tę operację w Krajinie. J. Elsässer, dz. cyt., s. $124-125$. 
który uznał, że przyszłe punkty zapalne na Bałkanach zwiąane są z następującymi państwami i regionami: Macedonia, Czarnogórą i Sandżakiem. Z analiz izraelskich służb wywiadowczych wynika, że islamskie organizacje humanitarne bez przerwy przesyłają środki finansowe dla muzułmanów pochodzenia bośniackiego i albańskiego, tworząc materialne podstawy przyszłych działań terrorystycznych $^{62}$. Bośniackie służby bezpieczeństwa oceniły, że liczba uzbrojonych radykalnych islamistów w tym kraju może wynosić 3 tys. Jeśli chodzi o zagrożenia terrorystyczne, to nie dotyczą one tylko radykalnego islamu. Trzeba bowiem także uwzględnić wpływy irańskiego wywiadu, który może wywierać nacisk na lokalne ośrodki władzy bośniackich Muzułmanów ${ }^{63}$.

\section{„Arabska wiosna ludów” determinantą rozwoju sieci terrorystycznej na Bałkanach}

Należy podkreślić, że ostatnie wydarzenia w basenie Morza Śródziemnego związane z "arabską wiosną ludów” mają ogromne znaczenie dla bezpieczeństwa na Starym Kontynencie. Do tej pory bowiem państwa arabskie nie stanowily większego zagrożenia, w okresie ,zimnej wojny” należały do tzw. ruchu państw niezaangażowanych, i chociaż nie były demokratyczne, ich polityczny, ekonomiczny i technologiczny rozwój był przewidywalny, sprzyjał więc zapewnieniu bezpieczeństwa zbiorowego. W swych analizach bośniaccy i serbscy eksperci wskazali, że obecnie cały basen Morza Śródziemnego, począwszy od Bałkanów aż do Afryki Północnej i Bliskiego Wschodu, znajduje się w nieprzewidywalnym procesie stadium przejściowego, którego wyniki nie są łatwe do ustalenia, podobnie jak nie można było określić, jaki kształt przyjmą procesy transformacyjne w państwach byłej Jugosławii ${ }^{64}$.

${ }^{62}$ Lieberman: Balkans the next target of Worldwide Jihad, 6 I 2010, http://serbianna.com/news/archives/3788 (dostęp 12 II 2012).

${ }^{63}$ Bosnia: 3,000 militants pose grave security threat', 13 VII 2010, http://www.adnkronos.com/AKI/English/Security/?id=3.1.677269022 (dostęp 12 II 2012).

${ }^{64}$ D. Trifunović, Dž. Galijašević, $d z$. cyt., s. 1-2 i n. Sytuacja polityczna i społeczna państw postjugosłowiańskich nadal nie jest stabilna, co potwierdza przypadek Serbii i Kosowa. Serbia co prawda 2 marca 2012 r. oficjalnie uzyskała status kandydata do UE i do końca 2012 r. spodziewa się otrzymać termin rozpoczęcia rozmów o pełnoprawnym członkostwie, jednak Serbowie nadal nie uznają niepodległości Kosowa. Nie mogą bowiem wystąpić przeciwko integralności terytorialnej swojego państwa. Wielu komentatorów zwróciło uwagę, że rozmowy Serbii z UE mogą rozpocząć się dopiero na początku 2013 r. Tadić: Očekujemo datum pregovora do kraja godine, 6 III 2012, http://www.politika.rs/rubrike/tema-dana/Tadic-Ocekujemo-datum-pregovora-do-kraja-godine.lt.html (dostęp 7 III 2012). W raporcie sekretarza generalnego ONZ Ban Ki-Moona, dotyczącym sytuacji w Kosowie za 
Wielu naukowców zadaje sobie pytanie, czy przemoc użyta do obalenia dyktatorów doprowadzi do demokratyzacji państw arabskich? Stanisław Sulowski zwrócił uwagę, że procesy demokratyczne zależą wyłącznie od ukształtowania się sceny politycznej w tych krajach oraz od czynników zewnętrznych, które mogą hamować bądź wspierać demokratyzację. Przy czym, istotnymi graczami są tu ugrupowania islamskie, głównie Bractwo Muzułmańskie, które w Egipcie i Jordanii ma swoje partie polityczne ${ }^{65}$. Zdaniem analityków z „Foreign Affairs”, jeśli „arabska wiosna ludów” zakończy się wzmocnieniem islamskich ruchów radykalnych, to w Europie Południowo-Wschodniej prawdopodobnie dojdzie do obniżenia poziomu bezpieczeństwa ${ }^{66}$. Oczywiście, trudno jest precyzyjnie przewidzieć, jaka będzie skala wpływu tych wydarzeń na sytuację polityczną na Bałkanach. Moga one jednak delimitować działania terrorystów i fundamentalistów. Fundusze dostarczane przez państwa arabskie zapewne będą służyć kreowaniu postaw związanych z radykalnym islamem. Ze zjawiskami niekorzystnymi, które rozwijają się po „arabskiej wiośnie ludów”, mamy już do czynienia. Islamiści bowiem w kilku krajach odnieśli sukcesy w wyborach parlamentarnych. W Egipcie wygrała je Partia Wolności i Sprawiedliwości, polityczna reprezentacja Bractwa Muzułmańskiego, która zdobyła 47\% głosów, drugie miejsce natomiast zajęła salaficka Partia Światła. Sytuacja polityczna w tym państwie jest daleka od stabilizacji, część społeczeństwa bowiem (przede wszystkim młodzi liberałowie) protestuje przeciwko rządom fundamentalistów ${ }^{67}$. W lutym i marcu 2012 r. w ogarniętej wojną domową i chaosem Syrii najostrzejsze walki toczyły się w mieście Homs, położonym strategicznie w centrum kraju, gdzie siły bezpieczeństwa zabiły ponad 7,5 tys. osób ${ }^{68}$.

Widzimy więc, że przemiany, które występują w państwach arabskich wiążą się z osłabieniem bezpieczeństwa oraz wzrostem islamskiego fundamen-

okres od 16 października 2011 do 15 stycznia 2012 r., stwierdzono co prawda zmniejszenie napięć, lecz nadal sytuację na tym terytorium uznawano za niestabilną, grożącą eskalacją konfliktu etnicznego. W ocenie polityków serbskich winą za taki stan rzeczy należy obciążyć władze albańskie w Prisztinie, które skazują kosowskich Serbów na życie w getcie - zob. Ban Ki Moon: Situation in the north permanent risks for Kosovo, 2 II 2012, http:// www.m-magazine.org/index.php/en/news/world/1990-ban-ki-moon-situation-in-the-north-a-permanent-risk-for-kosovo-.html (dostęp 8 III 2012); Zakończyto się posiedzenie RB ONZ poświęcone Kosowu, 9 II 2012, http://balkanistyka.org/wp/zakonczylo-sie-posiedzenie-rb-onz-poswiecone-kosowu/ (dostęp 7 III 2012).

${ }^{65}$ S. Sulowski, Bliski Wschód między demokratyzacja a rewolucja, [w:] Bliski Wschód coraz bliżej, red. J. Danecki, S. Sulowski, Warszawa 2011, s. 87-89.

66 J.A. Goldstone, J.T. Hazel Jr., Understanding the revolutions of 2011: weakness and resilience in middle Eastern autocracies, „Foreign Affairs” 2011, vol. 90, no. 3.

${ }^{67}$ M. Lipa, Armia dzieli i rzqdzi, „Przegląd” 2012, nr 6, s. 30.

68 Dane te pochodzą z początku marca 2012 r., Syria zatrzymała konwój $z$ pomocq, 2 III 2012, http://wyborcza.pl/1,86748,11275506,Syria_zatrzymala_konwoj_z_pomoca. html (dostęp 2 III 2012). 
talizmu. Słuszna więc wydaje się teza, że ich wynikiem może być uzyskanie przewagi w tych krajach przez ideologię reprezentowana przez Osamę bin Ladena, Ajmana Az-Zawahiriego oraz innych liderów Al-Kaidy. Przy czym nie należy wierzyć, by można było kontrolować radykalny islam oraz związany z nim terroryzm. Zjawisko terroryzmu fundamentalistycznego łączy się bowiem z uniwersalizmem, co oznacza, że może się on bardzo szybko rozprzestrzeniać, a także towarzyszyć każdej formie kultu religijnego na świecie. W ocenie badaczy tej problematyki jest to forma szczególnie niebezpieczna i trudna do pokonania, której nasilenie nastapiło pod koniec XX i na początku XXI w., sprawiając, iż czynniki religijne stały się jedną z głównych przyczyn działalności terrorystycznej, co też znajduje potwierdzenie w Bośni i Hercegowinie ${ }^{69}$.

Gilles de Kerchove, koordynator UE ds. zwalczania terroryzmu, ocenił, że jedynie w dalszej perspektywie czasowej „arabska wiosna ludów” może mieć pozytywny wpływ na bezpieczeństwo, obecnie jednak niesie ryzyko ponownej koncentracji takich sił Al-Kaidy, jak np. AQAP (Al-Qaeda in the Arabian Peninsula $^{70}$ ) czy grupa AQIM (Al-Qaeda Organization in the Islamic Maghreb) ${ }^{71}$, której najemni bojownicy walczyli w szeregach libijskich powstańców. Jednocześnie podkreślił on, że Al-Kaida jest wciąż aktywna w Iraku i na Kaukazie, jej grupy są zaś przerzucane do Europy, stanowiąc poważny problem dla służb bezpieczeństwa Starego Kontynentu. Członkowie tej organizacji uczestniczą w szkoleniach w Afganistanie, Pakistanie i Somalii, by później dołączyć do dżihadu na różnych jego frontach ${ }^{72}$.

Mimo śmierci bin Ladena nadal istnieje zagrożenie, że fundamentaliści islamscy będą dominować $\mathrm{w}$ strukturach $\mathrm{Al}$-Kaidy, nikogo nie powinna więc dziwić popularność nurtów ekstremistycznych i wzrost liczby jego zwolenników w Bośni i Hercegowinie. W ocenie ekspertów, w Bośni przebywa około 100 tys. wyznawców wahhabizmu, którzy czekają na okazję, aby udowodnić, że są prawdziwymi „wojownikami Allaha”. ${ }^{\text {T3 }}$ Po demonstracjach ulicznych w Egipcie wypuszczono $\mathrm{z}$ więzień przeciwników prezydenta Hosniego Mubaraka,

${ }^{69}$ S. Wojciechowski, $d z$. cyt., s. 158. Ponadto sprawcy aktów terroru sa przekonani o defensywnym charakterze swoich działań, tłumaczą bowiem swoje poczynania tym, iż są one odpowiedzią na agresję ze strony innych. Nie obawiają się także utraty popularności i w związku z tym częściej podejmują działania brutalne. M. Madej, Zagrożenia asymetryczne bezpieczeństwa państw obszaru transatlantyckiego, Warszawa 2007, s. 140 i n. Więcej zob. M. Ranstorp, Terrorism in the name of religion, „Journal of International Affairs" 1996, no. 1.

70 Odłam Al-Kaidy działający na Półwyspie Arabskim.

71 Stowarzyszone z Al-Kaidą grupy, które prowadzą akcje terrorystyczne w państwach Maghrebu.

${ }^{72}$ Arabska wiosna ludów ryzykowna dla bezpieczeństwa, 5 IX 2011, http://wiadomosci.onet.pl (dostęp 12 II 2012).

${ }^{73}$ Egipćanin okuplja vehabije u BiH, $21 \mathrm{~V}$ 2011, http://www.rtv.rs/sr_lat/region/ egipcanin-okuplja-vehabije-u-bih_254995.html (dostęp 12 II 2012). 
wśród których było wielu radykalnych islamistów, wyznawców prowadzenia dżihadu i członków organizacji terrorystycznych, którzy zamierzali wrócić na pole walki ${ }^{74}$. Na wolność wyszedł także Imad al-Misri, Egipcjanin, komendant jednostki „El Mudžahedin”. Zanim nastapiła jego ekstradycja do Egiptu, nosił nazwisko Eslam Durmo i rezydował w Bośni. Al-Misri, który należy do radykalnej egipskiej frakcji Az-Zawahiriego, zaraz po powrocie do Bośni rozpoczął propagowanie zasad fundamentalizmu islamskiego. W lutym 2011 r. w Sarajewie oraz Travniku wygłosił wykłady na temat właściwej roli kobiet w islamie, natomiast w kwietniu 2011 r. w Bugojnie mówił o rozłamie wśród muzułmanów, który niszczy braterstwo wyznawców tej religiii ${ }^{75}$. Inne niepokojące wydarzenie zaszło 13 maja 2011 r., kiedy podczas kazania imam Bilal Bosnić w meczecie w Bihaciu gloryfikował bin Ladena jako prawdziwego muzułmańskiego wierzacego, który stał się męczennikiem, walcząc z nikczemnymi niewiernymi ${ }^{76}$. Źródła bośniackie wskazuja, że obecnie członkowie ruchu wahhabitów odbywają szkolenia wojskowe w miejscowości Mahnjača, na granicy gminy Teslić w Republice Serbskiej i Zenicy w Federacji $\mathrm{BiH}^{77}$.

$$
* \quad * \quad *
$$

Nieprzewidywalne procesy transformacyjne związane $\mathrm{z}$ „arabską wiosna ludów" świadczą o tym, że nie można lekceważyć rozwijającego się fundamentalizmu islamskiego, który już oddziałuje na terytorium Bałkanów. Trzeba pamiętać, że Półwysep Bałkański jest pomostem do Azji Mniejszej oraz na Bliski Wschód. Wzrost liczby zwolenników radykalnych nurtów islamu w tych regionach stwarza kolejną możliwość ekspansji sieci globalnego dżihadu, która rozwija się na Bałkanach Zachodnich, obejmując swoim zasięgiem nie tylko Bośnię i Hercegowinę, ale także Macedonię, Kosowo, Sandżak oraz Albanię. Bałkańskie i amerykańskie służby wywiadowcze mają świadomość, że Al-Kaida operuje w tej „bałkańskiej komórce”, której bazy logistyczne usytuowane sa w Chorwacji, Słowenii, we Włoszech (Mediolan, Ankona) oraz w Austrii (Wiedeń stanowi główne centrum terrorystyczne Al-Kaidy na Bałkany). W Europie ta cała struktura organizacyjna nosi nazwę „Białej Al-Kaidy”. Lokalni eksperci ds. bezpieczeństwa podejmują wysiłki mające na celu zwalczenie terroryzmu, ale bezustannie napotykaja przeciwności, które utrudniają im skuteczne działanie. Wielu badaczy wskazuje, że werbowanie terrorystów do nowych siatek na największą skalę odbywa się w Bośni i Hercegowinie oraz Serbii. Co prawda,

\footnotetext{
${ }^{74}$ Arabska wiosna ludów...

${ }_{75}$ Egipćanin okuplja vehabije...

76 Tamże.

77 Tamíe.
} 
Evan Kohlmann podkreślił, że islamscy ekstremiści nigdy nie mieli szansy rekrutowania w Bośni większej liczby zwolenników, ani też zbudowania państwa islamskiego w Europie. W jego ocenie, Bośnia zyskała znaczenie tylko jako miejsce, gdzie można szkolić terrorystów i dawać im możliwość ukrycia się przed wymiarem ścigania ${ }^{78}$. Niedocenianie tego problemu może jednak mieć katastrofalne skutki. Wahhabici, z których kręgów często wywodzą się terroryści, cieszą się ochroną i opieką religijnych oraz państwowych autorytetów Bośni i Hercegowiny, kraju przejawiającego znaczną dysfunkcjonalność polityczna ${ }^{79}$, którego trzy narody posiadają odrębną wizję własnej państwowości. Od początku zakończenia wojny domowej utrzymuje się tam wysoki poziom napięć etnicznych, co sprawia, że na tym terytorium występuje „uśpiony” konflikt etniczny ${ }^{80}$. Kraj z tak osłabionym aparatem państwowym łatwo może zostać opanowany przez ekstremistów czy fundamentalistów, tym bardziej że w ocenie D. Trifunovicia wyznawcy wahhabizmu, zyskawszy coraz większe wpływy w tej części Starego Kontynentu, nie tylko rekrutują „Białą Al-Kaidę”, ale także dążą do ustanowienia „Bałkańskiego Kalifatu”", który obejmowałby zarówno Bośnię i Hercegowinę, jak też inne państwa. Nie jest to zagrożenie wyimaginowane, gdy spojrzymy na rosnące wpływy ludności pochodzenia albańskiego w Kosowie czy Macedonii. Bez wątpienia rozwijająca się w tym regionie baza globalnego dżihadu może doprowadzić do diametralnych zmian politycznych w państwach postjugosłowiańskich, zwłaszcza że terroryzmem posługiwali się np. Kosowarzy w swych dążeniach do ustanowienia niezależnego państwa albańskiego, które w XXI w. z sukcesem zagroziło integralności terytorialnej Serbii. Istotne jest więc wzmożenie wysiłków na rzecz demokratyzacji tych państw, aby można było $\mathrm{w}$ porę zapobiegać zagrożeniom związanym $\mathrm{z}$ fundamentalizmem islamskim. Organizowanie islamskich instytucji na Bałkanach za środki dostarczane przez bogate państwa muzułmańskie - to tylko jeden biegun działalności służący wspieraniu religijnej i kulturowej indoktrynacji społeczności na Bałkanach. Można go określić jako soft power oddziaływania muzułmanów w tym regionie.

${ }^{78} \mathrm{~W}$ ocenie Kohlmanna, bośniaccy Muzułmanie mieli cele odmienne od sfrustrowanych Arabów, gotowych oddać życie za wiarę. Bośniacy bowiem walczyli tylko o przeżycie, a ich europejska odmiana islamu nie miała niczego wspólnego z fundamentalizmem. Trudno jednak zgodzić się z tą oceną, biorąc pod uwagę wzrost znaczenia wahhabizmu po wojnie domowej w Bośni i Hercegowinie oraz na Bałkanach. E. Kohlmann, Al-Qaida’s Jihad in Europe. The Afghan-Bosnian Network, Oxford-New York 2004, s. 230.

${ }^{79}$ M. Szpala, Bośnia i Hercegowina: skonfliktowane elity pod presja kryzysu, 15 II 2012, http://www.osw.waw.pl/pl/publikacje/best/2012-02-15/bosnia-i-hercegowina-skonfliktowane-elity-pod-presja-kryzysu (dostęp 17 II 2012).

${ }^{80}$ D. Gibas-Krzak, Tendencje separatystyczne na Batkanach, „Bellona” 2009, nr 3, s. 108 .

${ }^{81}$ D. Trifunović, Threat to International Security - Terrorism in South East Europe, Al Qaeda \& Wahhabi Network, 6 III 2012 (mps udostępniony autorce artykułu), s. 1 i n. 
Jednocześnie nie należy zapominać, że z radykalnymi nurtami islamu wiąże się najbardziej trudne do zwalczenia zagrożenie asymetryczne XXI w., którym jest terroryzm o podłożu fundamentalistycznym, stanowiący hard power procesów związanych z ekspansją muzułmanów w tej części Europy.

Aby uniknąc niebezpieczeństw związanych z rozwojem fundamentalizmu islamskiego, państwa i społeczeństwa powinny podjąc szereg działań kompleksowych. Powtarzanie polityki prowadzonej przez władze „drugiej” Jugosławii, które w okresie „zimnej wojny” nie doceniły zagrożeń wynikających z rosnącej pozycji muzułmanów, nie służy wzmacnianiu bezpieczeństwa. Podobnych błędów nie ustrzegli się także Amerykanie w latach 80. XX w. Wspierając muzułmanów w Afganistanie, podejmowali bowiem działania obliczone jedynie na doraźne sukcesy, czego efekty świat odczuwa do dzisiaj. Identyczną porażkę poniosły państwa Zachodu promujące muzułmanów w czasie rozpadu Jugosławii, co dzięki propagandzie medialnej doprowadziło do uznania przez świat, że to wyznawcy islamu ponieśli najdotkliwsze straty w czasie tego konfliktu. Mit serbskiej winy za całe zło, które dokonało się na Bałkanach podczas wojny domowej związanej z rozpadem Jugosławii, na zawsze powinien zostać usunięty z historii współczesnych stosunków międzynarodowych, nie tylko bowiem Serbowie popełniali zbrodnie wojenne, ale znaleźli się także po stronie ofiar. Jedynym skutecznym rozwiązaniem mogącym wpłynąć na poprawę bezpieczeństwa $\mathrm{w}$ tym regionie wydaje się więc zintensyfikowanie procesów integracyjnych krajów postjugosłowiańskich z UE i NATO, wdrażanie procedur służących budowaniu demokratycznych społeczeństw, a także podjęcie ścisłej współpracy między służbami specjalnymi poszczególnych państw w celu zahamowania penetracji Starego Kontynentu przez islamskich fundamentalistów. 